\title{
Sedimentary environment and tectonic controls of the Snochowice Beds (Lower Jurassic, western margin of the Holy Cross Mountains, Poland)
}

\author{
Małgorzata KOZŁOWSKA
}

Kozłowska M. (2012) - Sedimentary environment and tectonic controls of the Snochowice Beds (Lower Jurassic, western margin of the Holy Cross Mountains, Poland). Geol. Quart., 56 (2): 299-314, doi: 10.7306/gq.1023

\begin{abstract}
The Snochowice Beds represent the lowermost part of the Lower Jurassic succession in the western part of the Mesozoic margin of the Holy Cross Mountains (Central Poland). This thick, gravelly has a different lithological character to other Lower Jurassic sandy and fine-grained deposits. Eight lithofacies have been distinguished, mainly gravelly and sandy, grouped into four genetic associations: M massive gravels, interpreted as clast-rich debris flow deposits, $\mathrm{G}$ - horizontally to cross-stratified gravels, interpreted as gravelly bars and bedforms, $\mathrm{S}$ - cross-stratified and massive sandstones, interpreted as sandy bars and bedforms and $\mathrm{F}$ - massive mudstones and claystones, generally fine-grained deposits, interpreted as overbank deposits. Analysis of depositional geometry and lithofacies successions allowed reconstruction of the sedimentary environment: landforms of alluvial fan type, formed mainly by braided river processes and rarely by sediment gravity flows. A decrease in the thickness and content of gravelly lithofacies towards the north and north-east is documented. Analysis of transport directions has revealed that the clastic material was transported toward the north and north-east, perpendicular to the main faults fringing the basin. Depositional geometry facies and palaeocurrent patterns of the Snochowice Beds indicate that sedimentation was controlled by tectonic activity.
\end{abstract}

Małgorzata Kozłowska, Institute of Geology, University of Warsaw, wirki i Wigury, 93, 02-089 Warszawa, Poland, e-mail: mmkozlowska@uw.edu.pl (received: October 22, 2010; accepted: March 12, 2012; first published online: June 6, 2012).

Key words: Lower Jurassic, gravels, clast-rich debris flows, streamflow dominated alluvial fans, tectonic control.

\section{INTRODUCTION}

The Lower Jurassic of the Mesozoic margin of the Holy Cross Mountains (MHCM; Fig. 1) is represented by various siliciclastic deposits, known from rare surface occurrences and from boreholes. Lithological, stratigraphical and sedimentological studies of the Lower Jurassic deposits in the MHCM have demonstrated their mixed continental and marginal-marine character (Karaszewski, 1962; Jurkiewiczowa, 1967; Karaszewski and Kopik, 1970; Pieńkowski, 1980, 1983, 2004, 2006). The lowermost part of the Jurassic succession (the lower Hettangian; the Zagaje Fm. sensu Pieńkowski, 2004) is dominated by fine-grained sandstones and heterolithic, in places with plant remains and coal intercalations of alluvial and lacustrine origin. Locally, in the western part of the MHCM, the lowermost part of the Lower Jurassic succession (possibly also upper Rhaetian; see Pieńkowski, 2004, 2006) consists of thick $(5-70 \mathrm{~m})$ gravels and conglomerates, known as the Snochowice Beds. The name Snochowice Beds was introduced by Dadlez (1962) as an informal lithostratigraphic unit for the local Lower Jurassic gravelly-sandy deposits. They were described from a few gravel pits near the villages of Snochowice and Ruda Pilczycka (Fig. 1). The Snochowice Beds were also documented by Jurkiewiczowa (1967) during her geological work near Pilczyca and Fałków (gravel pits around Ruda Pilczycka, Lipa and Szkucin; Fig. 1). First Jurkiewiczowa (1967), and later Pieńkowski (1983, 2004) observed that deposition of the Snochowice Beds was of braided river depositional facies. But it was difficult to explain how such high-energy alluvial environments could develop in a lowlands area - the Early Jurassic lowland-type palaeorelief inferred for the MHCM being in sufficient to explain the presence and development of broad braid plains. This paper describes the lithofacies relations and regional extent of the Snochowice Beds, their relation with other Lower Jurassic deposits interpreted as their age-equivalents, and the reconstruction of the Snochowice Beds sedimentary environment. The sedimentological analysis presented herein together with earlier data and interpretations (Pieńkowski, 1980, 1983, 2004; Brański, 2006) help explain the sedimentary controls on this unique Lower Jurassic gravelly unit in the western part of the MHCM in the context of regional palaeogeography and structural basin development. 


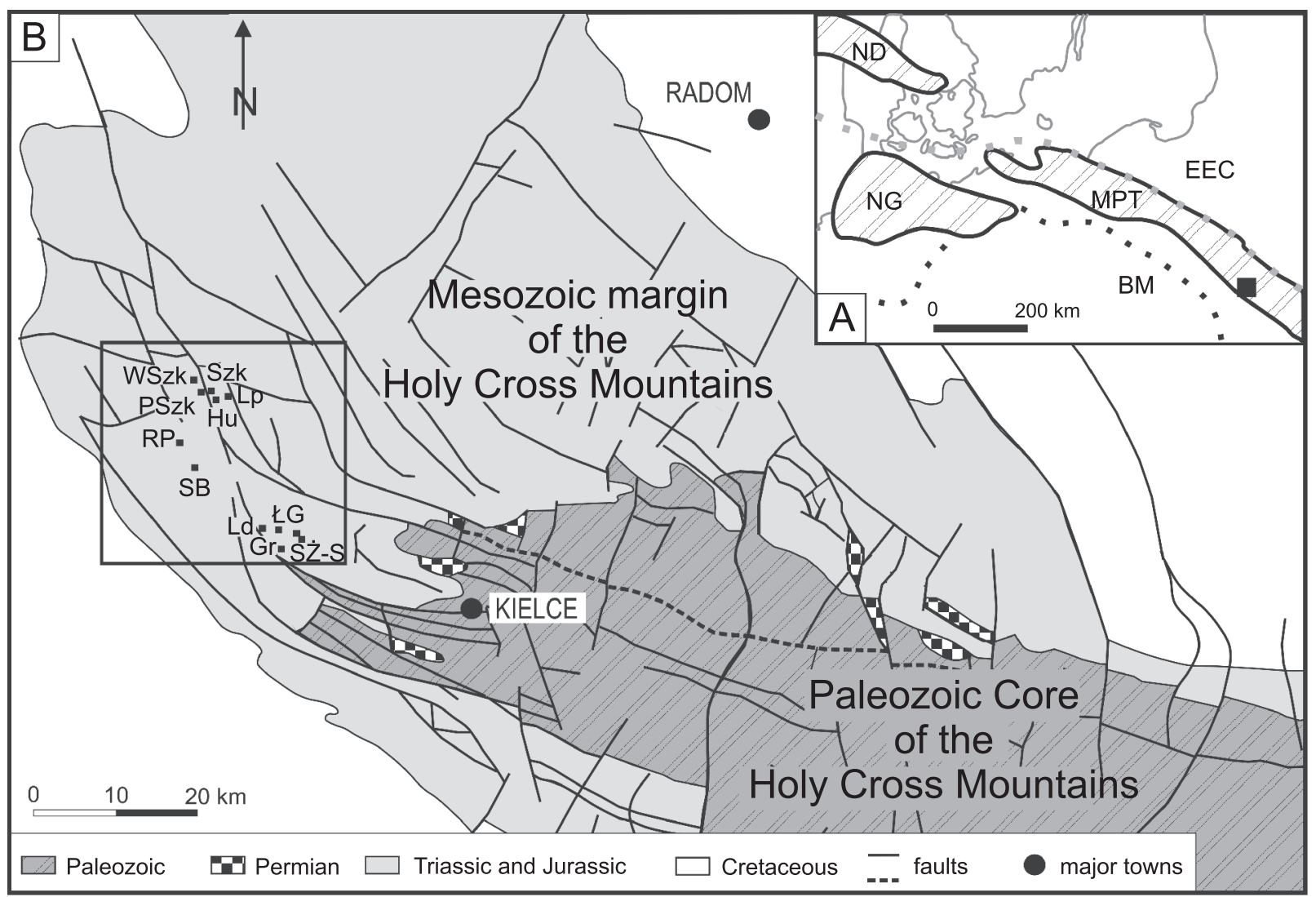

Fig. 1. Geological sketch maps

A - geological setting of the Mid-Polish Trough Basin (after Dadlez et al., 1995, simplified); BM - Bohemian Massif, EEC - East European Craton, MPT - depocentre of Mid-Polish Trough Basin, ND - North Danish Basin, NG - North German Basin; light grey dotted line - Caledonian deformation front, black doted line-Variscan deformation front, black square - study area; B - geological sketch map of the MHCM (after Wróblewski, 2000, simplified); black square - study area (exposures: SŻ-S - Snochowice Żwirownia-Skałki, ŁG - Łopuszno-Górki, Gr Grabownica, Ld - Ludwików, RP - Ruda Pilczycka, SB - Słupia-Bukowie, Lp - Lipa, Szk - Szkucin, PSzk - Piekło Szkucińskie, WSzk Wola Szkucka, Hu - Hucisko)

\section{GEOLOGICAL SETTING}

The Lower Jurassic sedimentary rocks of the MHCM were deposited in the marginal, southeastern part of an epicontinental basin, termed the Polish Basin and also the Mid-Polish Trough Basin (MPT; Pieńkowski, 2004). The Polish Basin was the easternmost part of the Permian-Mesozoic north-west European basin and linked continuously with the North Danish Basin to the north-west, also communicating with the German basins in the west and being intermittently connected with the eastern and southern (Tethyan) basins (see fig. 1 from Dadlez et al., 1995). The MPT was located over the boundary between two major structural units: the European Phanerozoic crustal domain to the west (Paleozoic Platform of Western and Central Europe) and the European Proterozoic crustal domain to the east (Precambrian East European Craton - EEC), within the Teisseyre-Tornquist Zone (TTZ sensu Guterch et al., 1986), which is part of the major lineament, the Trans-European Suture Zone (TESZ; Ziegler, 1992; Dadlez et al., 1995; Dadlez, 2006). In the early Permian the post-Variscan crustal destabilization of Western Europe triggered extensional tectonic stresses, expressed as marked tec- tonic subsidence and volcanic activity in some basins of Central Europe developed along the TTZ (Dadlez et al., 1995). As a prelude, tectonic and sedimentary events took place in a newly formed basin (the MPT), producing thick, volcanic and pyroclastic successions (Dadlez, 1982; Dadlez et al., 1995). Late Permian/Early Triassic tectonic activity finally determined the boundaries and shape of the Polish Basin (Dadlez, 1982; Dadlez et al., 1995).

The structural position of the MPT was affected by frequent tectonic events, leading to changes in the subsidence rate and playing a significant role during Mesozoic sedimentation (Dadlez et al., 1995; Dadlez, 2006). The rapid increase in subsidence continued from the end of Permian into the Late Triassic, caused the sedimentation of the Early Triassic red terrigenous series, the Middle Triassic carbonate-evaporite succession and the Late Triassic terrigenous rocks in the MPT (Marek, 1988; Dadlez et al., 1995). In the Early Jurassic the subsidence rate in the MPT was more constant and slower than in the Triassic (Dadlez et al., 1995). In the northwestern and central parts of the Polish Basin mainly sandy-muddy deposits of marginal marine origin formed: of deltaic, barrier-lagoon and open marine facies (Pieńkowski, 2004). Siliciclastic sedimentation continued to the end of the Jurassic in marginal ma- 
rine and open marine conditions (Karaszewski and Kopik, 1970; Pieńkowski, 1983, 2004, 2006; Marek, 1988).

In some parts of the basin, in the MHCM, at the end of Triassic - there was a reduced rate of subsidence, related to rifting processes in the Tethyan domains of south Central Europe as well as in the Arctic - North Atlantic area in northwestern Europe (Scheck-Wenderoth et al., 2008). Local minor inversions were expressed as depositional gaps or erosional unconformities in the succession (Dadlez et al., 1995). In some parts of the basin synsedimentary fault movements were documented (Scheck-Wenderoth et al., 2008). In consequence, in the MHCM, the Late Triassic, locally into the Sinemurian, was a time of structural reorganization (Dadlez, 1982; Dadlez et al., 1995; Scheck-Wenderoth et al., 2008).

Early Jurassic siliciclastic sedimentation in the MHCM began with renewed subsidence (Brański, 2006). These changes triggered the development of alluvial depositional systems (Karaszewski and Kopik, 1970; Pieńkowski, 1983, 2004, 2006). The lowermost part of the Jurassic profile is represented by thick successions of sandstones and heterolithic deposits. These contain plant remains, palaeosoil horizons and thin coal layers. They are typical cycles of meandering river and lacustrine systems developed in lowlands areas (the Zagaje Fm. sensu Pieńkowski, 2004; Jurkiewiczowa, 1967; Karaszewski and Kopik; 1970; Pieńkowski, 1983, 2004). The thick, gravelly succession of the Lower Jurassic - the Snochowice Beds - because of their different lithology, were interpreted as fluvial, though braided river deposits (Jurkiewiczowa, 1967; Pieńkowski, 1983, 2004, 2006). Subsequent sedimentation, from the Sinemurian into the Mid Jurassic in the MHCM, took place in marginal-marine, deltaic and barrier-lagoonal, and finally in offshore and shoreface conditions (Pieńkowski, 2004, 2006).

From the Late Cretaceous to the Paleogene the Permian-Mesozoic sedimentary rocks of the Mid-Polish Trough were folded (Dadlez et al., 1995; Dadlez, 2006). The structural inversion of the MPT was caused by the earliest Alpine collisional movements, as in all Central European basins (Ziegler,

\begin{tabular}{|c|c|c|c|c|c|c|}
\hline \multicolumn{3}{|c|}{$\begin{array}{c}\text { CHRONOSTRA- } \\
\text { TIGRAPHY }\end{array}$} & $\begin{array}{c}\text { Dadlez (1962) } \\
\text { Snochowice } \\
\text { area }\end{array}$ & $\begin{array}{c}\text { Pawłowska } \\
(1962) \\
\text { Szvdłów area }\end{array}$ & $\begin{array}{c}\text { Jurkiewiczowa } \\
(1967) \\
\text { Przedbórz area }\end{array}$ & $\begin{array}{l}\text { Pieńkowski } \\
(2004)\end{array}$ \\
\hline \multirow{6}{*}{ 过 } & 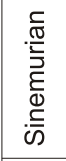 & ”े & \multirow[t]{3}{*}{$?$} & $?$ & $\begin{array}{l}\text { Zarzecze } \\
\text { series }\end{array}$ & $\begin{array}{l}\text { Ostrowiec } \\
\text { Formation }\end{array}$ \\
\hline & \multirow{5}{*}{\multicolumn{2}{|c|}{ 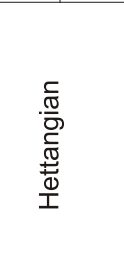 }} & & Skłoby and & Zagaje and & $\begin{array}{c}\text { Ore-bearing } \\
\text { Przysucha Fm. }\end{array}$ \\
\hline & & & & $\begin{array}{l}\text { Lalzerzes } \\
\text { series }\end{array}$ & $\begin{array}{l}\text { series } \\
\text { s. }\end{array}$ & \multirow{2}{*}{$\begin{array}{l}\text { Skłoby } \\
\text { Formation }\end{array}$} \\
\hline & & & $\begin{array}{c}\text { Snochowice } \\
\text { Beds }\end{array}$ & $\begin{array}{c}\text { Snochowice } \\
\text { Beds }\end{array}$ & \begin{tabular}{|c|} 
Snochowice \\
Beds
\end{tabular} & \\
\hline & & & $?$ & \multirow[b]{2}{*}{$\begin{array}{l}\text { Zagaje } \\
\text { series }\end{array}$} & \multirow{3}{*}{ 5ous } & Huta Mudstone Mb. \\
\hline & & & \multirow[b]{2}{*}{$?$} & & & \multirow[t]{3}{*}{$\begin{array}{c}\text { Zagaje } \\
\text { Formation }\end{array}$} \\
\hline \multirow{2}{*}{ 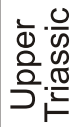 } & \multirow{2}{*}{\multicolumn{2}{|c|}{ 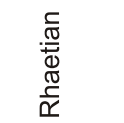 }} & & $?$ & & \\
\hline & & & & & & \\
\hline
\end{tabular}

Fig. 2. The lithostratigraphic position of the Snochowice Beds in the lowermost part of the Jurassic succession
1992; Dadlez et al., 1995; Scheck-Wenderoth et al., 2008). In the MHCM the Alpine tectonic movements took place during the Mid Cretaceous and Paleogene (Kutek and Głazek, 1972; Dadlez et al., 1995). Then, the Permian-Mesozoic rocks were gently folded (the dip is between 5 and $10^{\circ}$ ) and cut by many faults. The main folds are elongated with axes trending between 100 and $135^{\circ}$, parallel to the edge of the East European Craton (Dadlez, 1982; Dadlez et al., 1995) and in concordance with the edge of the Małopolska Block (sensu Buła et al., 1997; Buła, 2000).

\section{STRATIGRAPHY AND COMPOSITION OF THE SNOCHOWICE BEDS}

The deposits analysed represent the lowermost part of the Lower Jurassic succession - the lowermost part of the Hettangian, and probably the upper part of the Rhaetian (Jurkiewiczowa, 1967; Karaszewski and Kopik; 1970; Pieńkowski, 2004, 2006). The contact with the underlying red Upper Triassic (Norian) mudstones is easy to identify in the field as the lower boundary of the Snochowice Beds is sharp and erosional (Jurkiewiczowa, 1967; Filonowicz and Lindner, 1982). Thickness estimates of the Snochowice Beds vary: Dadlez (1962) proposed $30 \mathrm{~m}$, but only for the lowermost part of the gravelly unit near Pilczyca, and Filonowicz and Lindner (1982) proposed $90 \mathrm{~m}$ for the gravels which occur near Snochowice village. This estimate was based on their field work and also on results given by Karaszewski $(1960,1962)$ and Jurkiewiczowa (1967). The difficulty in making thickness estimates is caused by poor knowledge of the stratigraphy and boundaries of this informal unit and also because the gravels described have an alluvial lens-shaped geometry. In addition, the sedimentary record is incomplete - the succession is usually truncated at the top - near Łopuszno the Snochowice Beds are overlain by black Jurassic claystones, which were referred to the Bajocian(?)-Bathonian by Barski (1999). Towards the north and north-west (near Pilczyca and Przedbórz), at the top of the gravelly deposits, younger members of the Lower Jurassic succession were documented - Hettangian fine-grained sandstones and mudrocks with plant remains (Jurkiewiczowa, 1967; Pieńkowski, 1983, 2004).

The stratigraphical position of the Snochowice Beds has been discussed extensively (Pawłowska, 1962; Jurkiewiczowa, 1967; Pieńkowski, 2004; see Fig. 2). Indirectly, its biostratigraphical position can be inferred as younger than Norian and older than upper Sinemurian because Marcinkiewicz (1971) found the megaspores Nathorstisporites hopliticus Jung and Lycostrobus scotti Nathorst in the overlying fine-grained deposits near Przedbórz. These palynomorphs indicate a Hettangian and early Sinemurian age. More direct determination of the biostratigraphical position of the Snochowice Beds is difficult, prob- 
ably impossible, because of the absence of index fossils in these continental deposits. Sequence stratigraphy correlation of Lower Jurassic deposits in Central Poland, performed by Pieńkowski (2004, 2006), suggests that the Zagaje Formation is (?)middle-upper Rhaetian/lower Hettangian in age. Pieńkowski (2004) included the Snochowice Beds into the Zagaje Formation and thus provided an age of gravelly unit (Fig. 2).

The Snochowice Beds are poorly sorted. They have a mixed, gravelly-sandy texture and the content of matrix is variable $(40-50 \%)$. Chemical analyses show that the matrix is mainly composed of fine, detrital quartz and kaolinite (10-15\%), and locally only of the former (Dadlez, 1962). The deposits are in part strongly hematitised and silicified.

The gravels are characterized by high petrographic maturity - they are mainly composed of well-rounded pebbles of vein quartz, quartzite, quartzose sandstone, lydite and other silicious rocks (Dadlez, 1962; Kozłowska, 2011). Petrographic studies have shown significant differences in composition between the Lower Jurassic gravelly unit and older, Permian, conglomerates, which are composed of local (autochthonous), Paleozoic, mainly Devonian carbonates (Kostecka, 1962; Dadlez, 1962; Kutek and Głazek, 1972; TeofilakMaliszewska, 1968; Maliszewska, 1997). This change in composition was caused by a change in the source areas. PostVariscan (late Permian and Early Triassic) erosion led to the formation of a peneplain in the MHCM (Kutek and Głazek, 1972). Then, generally from the Early Triassic, the clastic material was supplied from distant source areas, located far away to the south and south-east. The high petrographic maturity of the Snochowice Beds, as well as of all Triassic and Lower Jurassic clastic rocks, is the effect of multiple redeposition of detrital material from older, gravelly rocks and long transport from distant source areas - from the Pre-Carpathian Land and adjacent areas (Dadlez, 1962; Teofilak-Maliszewska, 1967; Maliszewska, 1997; Kozłowska, 2011).

\section{MATERIAL AND METHODS}

Sedimentological observations were made in small gravel pits and natural exposures near Snochowice, Ruda Pilczycka and Szkucin (Fig. 1). The lithology, sedimentary structures, lithofacies succession, and geometry and character of bed boundaries were documented in eleven sections (Figs. 3 and 4). Lithofacies were distinguished on the basis of grain-size, grain content and kind of matrix and sedimentary structures. A lithofacies code combined after Miall (1996) and Zieliński (1998) was used in the description (Tables 1 and 2).

Following lithofacies classification, facies associations were distinguished (Figs. 3 and 4). The lithofacies and relationship between them are presented on the photos (Figs. 5 and 6).

Palaeocurrent analysis was based on two types of measurements: the azimuths of the longest axes of pebbles in the gravelly facies and the cross-bedding dip azimuth in sandy and gravelly-sandy lithofacies. In the cross-bedded gravelly lithofacies the azimuths of the longest axes of the elongated pebbles were measured. In the analysis, only pebbles of diameter between 64 and $128 \mathrm{~mm}$, the most frequent in the
T a b l e 1

Lithofacies code combined after Miall (1996) and Zieliński (1998), used in this paper

\begin{tabular}{|l|c|}
\hline Symbols & Lithology \\
\hline G & gravel or/and conglomerate \\
\hline GD & diamictic gravel or/and conglomerate (silty-sandy matrix) \\
\hline GS & sandy gravel or/and conglomerate \\
\hline SG & gravelly sand or/and sandstone \\
\hline S & sand or/and sandstone \\
\hline SF & silty sand or/and sandstone \\
\hline F & siltstone or/and claystone \\
\hline Symbols & Sedimentary structures \\
\hline $\mathrm{m}$ & massive \\
\hline $\mathrm{g}$ & normal grading \\
\hline $\mathrm{h}$ & horizontal bedding \\
\hline 1 & low-angle cross-bedding \\
\hline $\mathrm{p}$ & tabular cross-bedding \\
\hline
\end{tabular}

Snochowice Beds gravels, were used. Because the azimuths of the longest axes generally are perpendicular to palaeoflow (according to Unrug, 1957), the measurements were-so converted to obtain the flow directions. The analysis included measurements of the tabular cross-bedding in the sandy and sandy-gravelly lithofacies. In most sections the sum of all measurements was above 50 for statistical significance. The Curray (1956) statistical method was used for calculation of the resultant vectors and their magnitudes.

The relationship of the Snochowice Beds to the Triassic basement was documented in the gravel pits (Figs. 3 and 4) and in many trenches. Besides field observations, the information about the thickness and the lithology of the Lower Jurassic and also about the lithology of the under- and overlying deposits were taken from archived borehole records (Fig. 7).

\section{SEDIMENTOLOGY}

\section{LITHOFACIES AND FACIES ASSOCIATIONS}

Eight lithofacies are distinguished within the Snochowice Beds on the base of grain size, sedimentary structures, content and type of matrix (Table 2). In the deposits analysed, no fossils were found.

The lithofacies are grouped in four facies associations:

- massive gravels - M;

- horizontally to cross-stratified gravels - G;

- cross-stratified and massive sandstones - S;

- massive mudstones and claystones $-\mathrm{F}$.

The identification of each association is based on the type and succession of sedimentary structures, the geometry of individual gravelly and sandy beds, and the relationship between particular facies.

THE M ASSOCIATION

The $\mathrm{M}$ association is built mainly of GDm/GSm deposits (Figs. 3 and 4 - especially the Łopuszno-Górki, Snochowice 


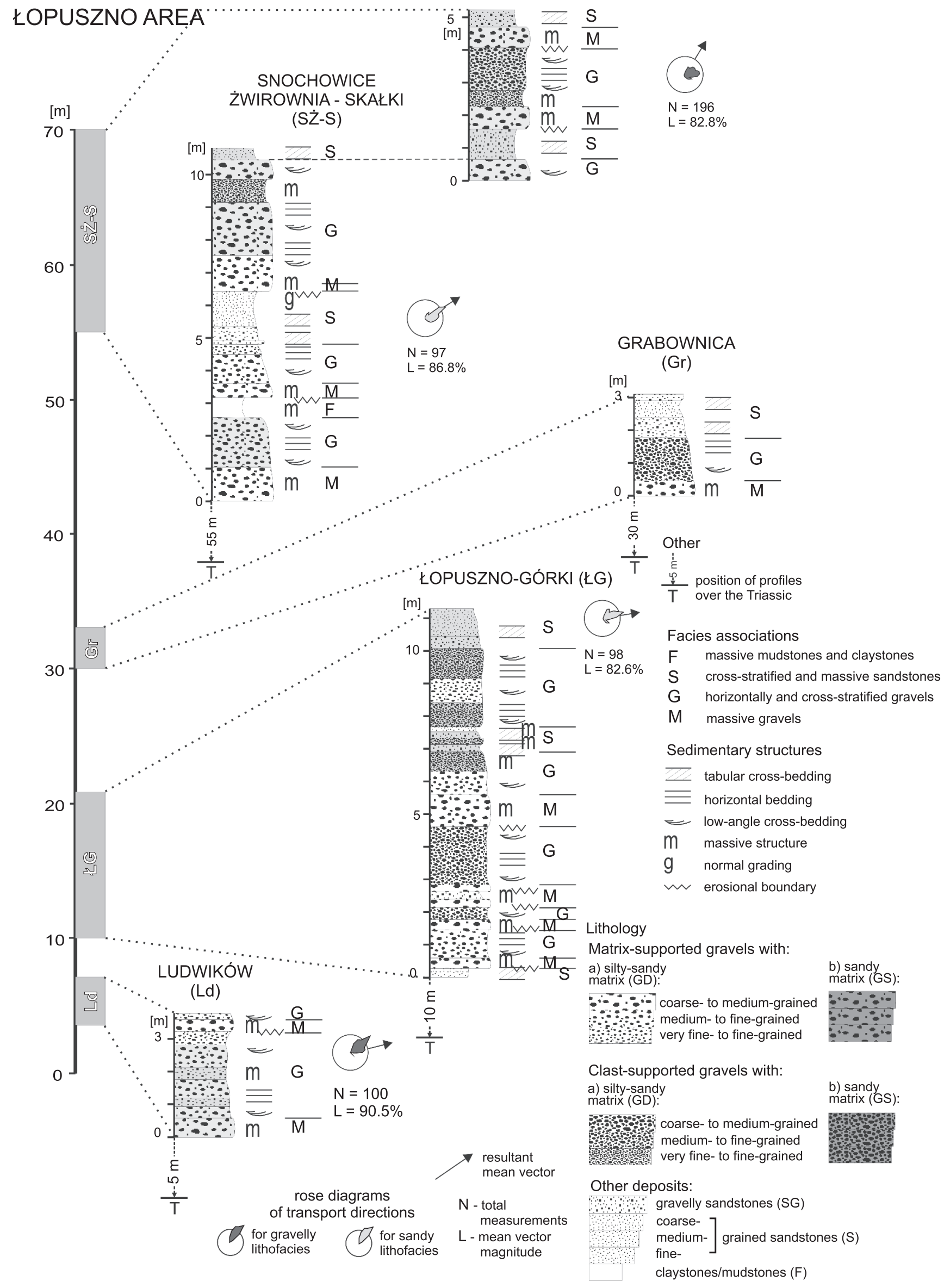

Fig. 3. Lithologies and sedimentary structures in sections in the Lopuszno area 
PILCZYCA-FAŁKÓW AREA
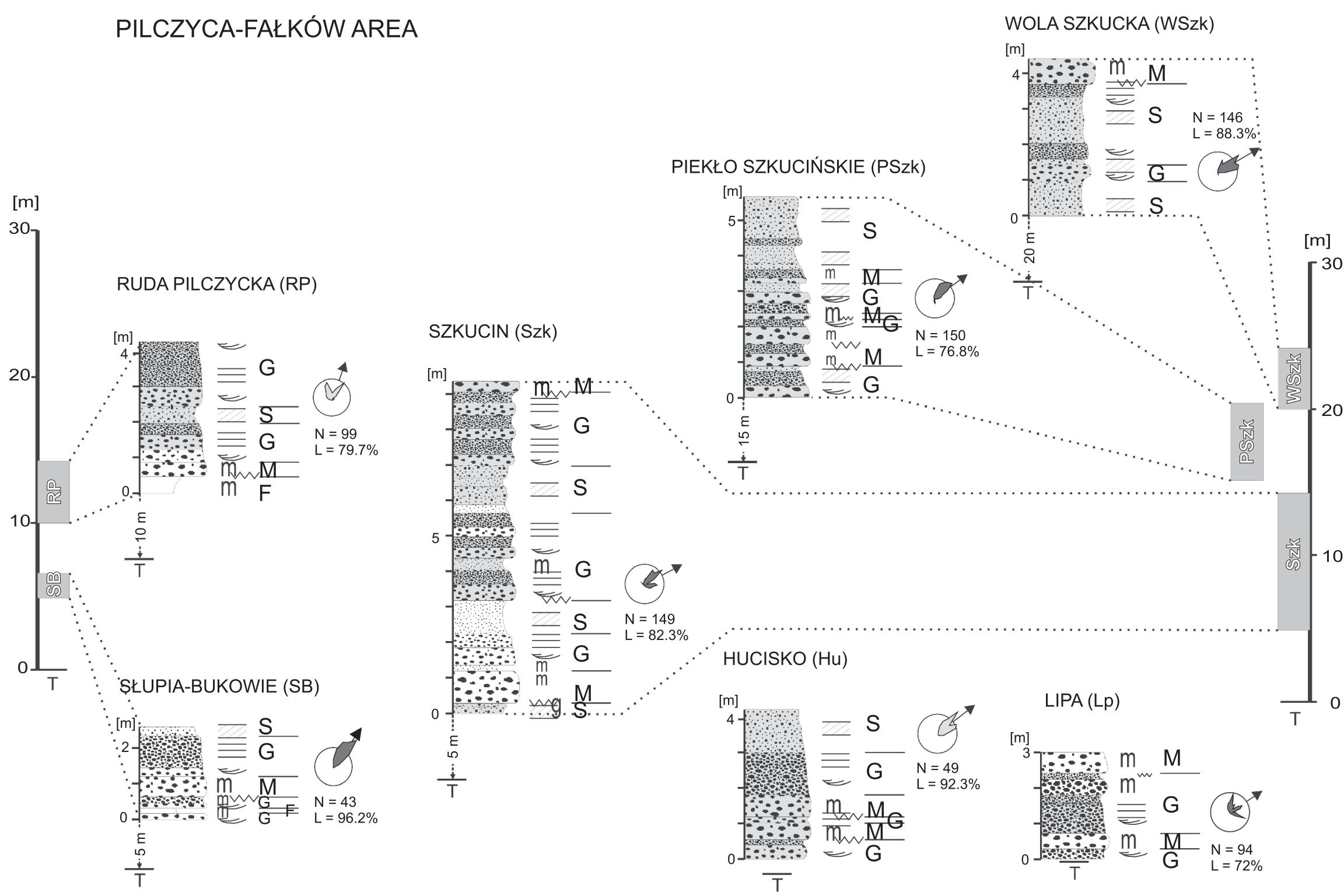

Fig. 4. Lithologies and sedimentary structures in sections in the Pilczyca-Falków area

For explanations see Figure 3 
Lithofacies distinguished

\begin{tabular}{|c|c|c|c|c|c|}
\hline $\begin{array}{l}\text { Lithofacies } \\
\text { code }\end{array}$ & Grain size and sedimentary structures & $\begin{array}{c}\text { Content and } \\
\text { kind of matrix }\end{array}$ & $\begin{array}{l}\text { Shape } \\
\text { of beds }\end{array}$ & $\begin{array}{l}\text { Thickness of beds } \\
\text { and lateral extent }\end{array}$ & Additional comments \\
\hline \multicolumn{6}{|c|}{ gravelly lithofacies } \\
\hline GDm/GSm & $\begin{array}{l}\text { massive, matrix-supported medium- } \\
\text { to coarse-grained gravels, sometimes } \\
\text { conglomerates } \\
\text { (GSm on the Fig. } 5 \mathrm{~A})\end{array}$ & $\begin{array}{l}40-50 \% \\
\text { silty-sandy or } \\
\quad \text { sandy }\end{array}$ & $\begin{array}{l}\text { tabular beds, } \\
\text { slightly } \\
\text { lenticular shape }\end{array}$ & $\begin{array}{l}\text { from tens of } \mathrm{cm} \text { to } \\
\text { one metre; lateral } \\
\text { extent - up to } 5 \mathrm{~m}\end{array}$ & $\begin{array}{l}\text { erosional character of lower } \\
\text { boundaries of beds; the massive } \\
\text { structure - irregular arrangement } \\
\text { of pebbles and matrix }\end{array}$ \\
\hline $\mathrm{Gm}$ & $\begin{array}{l}\text { massive, clast-supported fine- to very } \\
\text { fine-grained gravels } \\
\text { (Fig. 5B) }\end{array}$ & $\begin{array}{l}\text { 10-20\%; } \\
\text { mainly } \\
\text { silty-sandy, } \\
\text { less fre- } \\
\text { quently sandy }\end{array}$ & $\begin{array}{l}\text { very thin and } \\
\text { continuous beds }\end{array}$ & $\begin{array}{l}\text { up to } 0.5 \mathrm{~m} \text {; } \\
\text { considerable lateral } \\
\text { extent }\end{array}$ & $\begin{array}{l}\text { sharp lower boundaries of beds; } \\
\text { the massive structure - irregular } \\
\text { arrangement of pebbles }\end{array}$ \\
\hline Gh/GSh & $\begin{array}{l}\text { mainly fine- to medium-grained gravels } \\
\text { with horizontal bedding; both matrix- } \\
\text { and clast-supported gravels } \\
\text { (GSm on the Fig. 5C) }\end{array}$ & $\begin{array}{l}\text { from } 5-40 \% \\
\text { silty-sandy } \\
\quad \text { or sandy }\end{array}$ & $\begin{array}{l}\text { continuous } \\
\text { layers }\end{array}$ & $\begin{array}{l}20 \text { to } 50 \mathrm{~cm} \text { thick } \\
\text { and few metres lat- } \\
\text { eral } \\
\text { extent }\end{array}$ & $\begin{array}{l}\text { poorly visible horizontal bedding, } \\
\text { expressed by linear distribution of } \\
\text { elongated pebbles; fining-upward } \\
\text { grading common; erosional lower } \\
\text { boundaries of beds }\end{array}$ \\
\hline G1/GS1 & $\begin{array}{l}\text { fine- to medium-grained gravels with } \\
\text { low-angle cross-bedding (Figs. 5D and } \\
6 \mathrm{C} \text { ); matrix- to clast-supported (GSl on } \\
\text { the Figs. 5D and } 6 \mathrm{C} \text {; Gl on the Fig. } 6 \mathrm{~B} \text { ) }\end{array}$ & $\begin{array}{l}10 \text { to } 40 \% \\
\text { sandy or } \\
\text { silty-sandy } \\
\text { matrix }\end{array}$ & flat lenses & $\begin{array}{l}\text { up to } 0.8 \mathrm{~m} \text { thick } \\
\text { and several metres } \\
\text { long }\end{array}$ & $\begin{array}{l}\text { crude cross-bedding; erosional } \\
\text { lower boundaries of beds }\end{array}$ \\
\hline GSg & $\begin{array}{l}\text { sandy gravels with fining-upward } \\
\text { grading (Fig. 6A) }\end{array}$ & - & flat lenses & $\begin{array}{l}\text { thickness of beds } \\
\text { from } 10 \text { to } 30 \mathrm{~cm} \text {; } \\
\text { several metres of } \\
\text { the lateral extent }\end{array}$ & $\begin{array}{l}\text { sharp lower boundaries } \\
\text { of beds; usually overlain } \\
\text { by diamictic gravels }\end{array}$ \\
\hline \multicolumn{6}{|c|}{ sandy lithofacies } \\
\hline $\mathrm{Sp} / \mathrm{SG} / \mathrm{GSp}$ & $\begin{array}{l}\text { medium- to coarse-grained sandstones, } \\
\text { quite often gravelly sandstones with } \\
\text { medium-scale tabular cross-bedding } \\
\text { (Fig. 6B, D); matrix-supported }\end{array}$ & - & lenticular beds & $\begin{array}{l}\text { thickness from } 20 \text { to } \\
40 \mathrm{~cm} \text {; beds with } \\
\text { few metres lateral } \\
\text { extent }\end{array}$ & fining-upward grading \\
\hline $\mathrm{Sm} / \mathrm{SGm}$ & $\begin{array}{l}\text { massive coarse-grained and gravelly } \\
\text { sandstones (Fig. 6D) }\end{array}$ & - & $\begin{array}{l}\text { thin beds and } \\
\text { also irregular } \\
\text { lens }\end{array}$ & $\begin{array}{l}\text { thickness up to } 0.5 \\
\text { m; lateral extent }\end{array}$ & $\begin{array}{l}\text { the chaotic arrangement } \\
\text { of clasts and detrital matrix }\end{array}$ \\
\hline \multicolumn{6}{|c|}{-fines } \\
\hline Fm & $\begin{array}{l}\text { white or light grey massive clays or } \\
\text { claystones, quite often massive muds } \\
\text { or mudstones }\end{array}$ & - & $\begin{array}{l}\text { thin layers } \\
\text { or lenses }\end{array}$ & $\begin{array}{l}\text { layers up to } 20 \mathrm{~cm} \text {; } \\
\text { thick or irregular } \\
\text { lenses below } 30 \mathrm{~cm} \\
\text { thick }\end{array}$ & $\begin{array}{l}\text { thin layers; irregular lenses } \\
\text { in gravelly beds }\end{array}$ \\
\hline
\end{tabular}

wirownia-Skałki, Ruda Pilczycka, Lipa and Szkucin sections; see GSm on the Figs. 5A and 6C). The topmost parts of the association consists of more fine-grained deposits - usually massive gravelly sandstones - Sm/SGm (Figs. 3 and 4 - see the Łopuszno-Górki and Szkucin sections). The lower boundaries of the $\mathrm{M}$ association are erosional. The thickness of this association is between 0.5 to $1 \mathrm{~m}$. The lateral extent of the $\mathrm{M}$ association is from a few to more than ten metres. The GDm lithofacies is known mainly from the lower part, and the GSm lithofacies from the upper part, of the Snochowice Beds.

\section{THE G ASSOCIATION}

This association is generally represented by all types of gravelly-sandy deposits with low-angle cross-bedding and poorly visible horizontal bedding: lithofacies Gl/GSl and lithofacies Gh/GSh (Figs. 3 and 4 - Snochowice wirownia-Skałki, Ludwików, Lipa and Szkucin sections; Fig. 5C, D). Lithofacies Gm occurs in this association too, but less commonly than the Gl/GSl and Gh/GSh lithofacies. The Gm lithofacies was usually present in the lower part of the $\mathrm{G}$ association (see Fig. 3 Snochowice wirownia-Skałki section) or constituted thin $(0.2-0.5 \mathrm{~m})$ intercalations in gravels with horizontal or cross-bedding (see Fig. 4 - Lipa section). The lower boundary has an erosional character. The total thickness of the $\mathrm{G}$ association is about $1-3 \mathrm{~m}$, and its lateral extent is about $20-30 \mathrm{~m}$.

THE S ASSOCIATION

The $\mathrm{S}$ association is represented by lithofacies $\mathrm{Sp} / \mathrm{SGp} / \mathrm{GSp}$ (Figs. 3 and 4 - Snochowice wirownia-Skałki, Piekło Szkucińskie and Wola Szkucka sections; Fig. 6B, D). The lower boundaries of beds are erosional. The thickness of this association commonly attains about $1 \mathrm{~m}$, but it may range up to a few metres (for example in the Wola Szkucka section; see Fig. 4). A fining-upwards tendency is commonly observed in the sandy lithofacies of this association. In addition the gradual transition from very coarse- (mixed sandy and gravelly material) to medium-grained sandstones is accompanied with a decreasing thickness of cross-sets.

\section{THE F ASSOCIATION}

Very fine-grained sediments - massive white claystones and mudstones - are rare (Figs. 3 and 4 - Snochowice wirownia-Skałki and Ruda Pilczycka sections). The lower boundaries in both sections are depositional. In the Ruda Pilczycka section the mudstone layers drape the $\mathrm{S}$ association bedsets. They form thin (about $0.2 \mathrm{~m}$ ) layers, continuous on the 

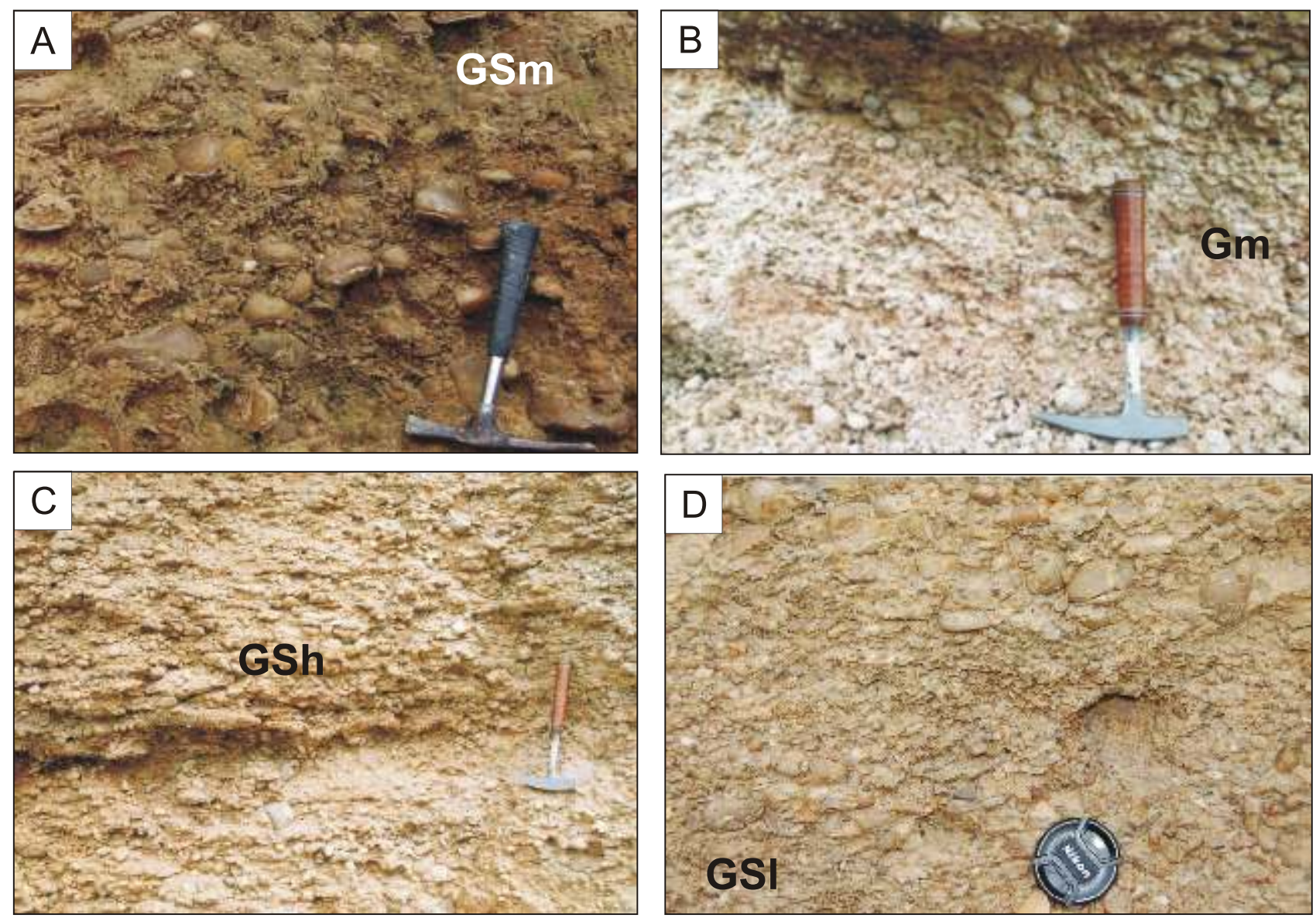

Fig. 5A - massive, matrix-supported sandy gravels (GSm lithofacies); documented exposures near the Lipa gravel pit; B - massive, clast-supported gravels (Gm lithofacies); Snochowice wirownia-Skałki; C - matrix-supported sandy gravels with horizontal bedding (GSh lithofacies); Lipa gravel pit; D - matrix-supported sandy gravels with low-angle cross bedding (GSI); Hucisko exposure

exposure scale, not longer than a few metres. At Snochowice wirownia, $0.1-0.3 \mathrm{~m}$ thick irregular lenses of mudstones and claystones are dispersed in the $\mathrm{G}$ deposits. Probably they are erosional remnants of thin, continuous layers. The top of association is overlain by $\mathrm{G}$ or $\mathrm{M}$ association deposits.

\section{DEPOSITIONAL GEOMETRY} OF THE SNOCHOWICE BEDS

Based on lithological and thickness variations, three zones of deposition may be distinguished within the Snochowice Beds: (1) the Łopuszno area - between Łopuszno, Snochowice, Grabownica and Ludwików, (2) the PilczycaFałków area - between Pilczyca, Ruda Pilczycka, Fałków and Lipa, (3) the area towards the north and north-east of Fałków and Lipa.

In the first area the Snochowice Beds are characterized by their maximum thickness (about 70 metres) and their domination by gravelly deposits (the area designated by the brown line on Fig. 7). In this area the topmost part of the Snochowice Beds is eroded and the unit is covered by Middle Jurassic black claystones. The $\mathrm{M}$ and $\mathrm{G}$ associations dominate the sections (Figs. 3 and 4). Moreover, the gravelly beds have their largest thickness. The $\mathrm{G}$ deposits are about $2.5-3 \mathrm{~m}$ thick and their lateral extent is up to $30 \mathrm{~m}$. The content of the $\mathrm{S}$ association is lower.

In the second area - between Pilczyca, Ruda Pilczycka, Fałków and Lipa - the Snochowice Beds are characterized by smaller thicknesses of smaller proportions of the gravelly lithofacies (the area designated by the yellow line on Fig. 7). The thickness varies: near Pilczyca and Ruda Pilczycka it is about $20 \mathrm{~m}$. Northwards, near Lipa and Szkucin, the gravelly-sandy deposits are 5-25 m thick. There is a general thickness decrease towards the north and north-east. The gravelly lithofacies content is lower than in the Łopuszno area. The beds of the $\mathrm{M}$ association are thinner and less frequent. A domination by the $\mathrm{G}$ and $\mathrm{S}$ associations prevails (Fig. 7). The average grain size of the $\mathrm{G}$ deposits is generally smaller - in the sections mainly fine-grained and very fine-grained gravels were noted. Moreover, a high content of sandy matrix in the gravelly lithofacies was observed. The $\mathrm{G}$ association units are only 1-2 metres thick and their lateral extent is smaller than in the Łopuszno area.

Towards the north and north-east of Fałków and Lipa, the Snochowice Beds are represented only by gravelly sandstones. In addition, they are very scarce in the Lower Jurassic succession and they form small intercalations 2-3 metres thick, among 

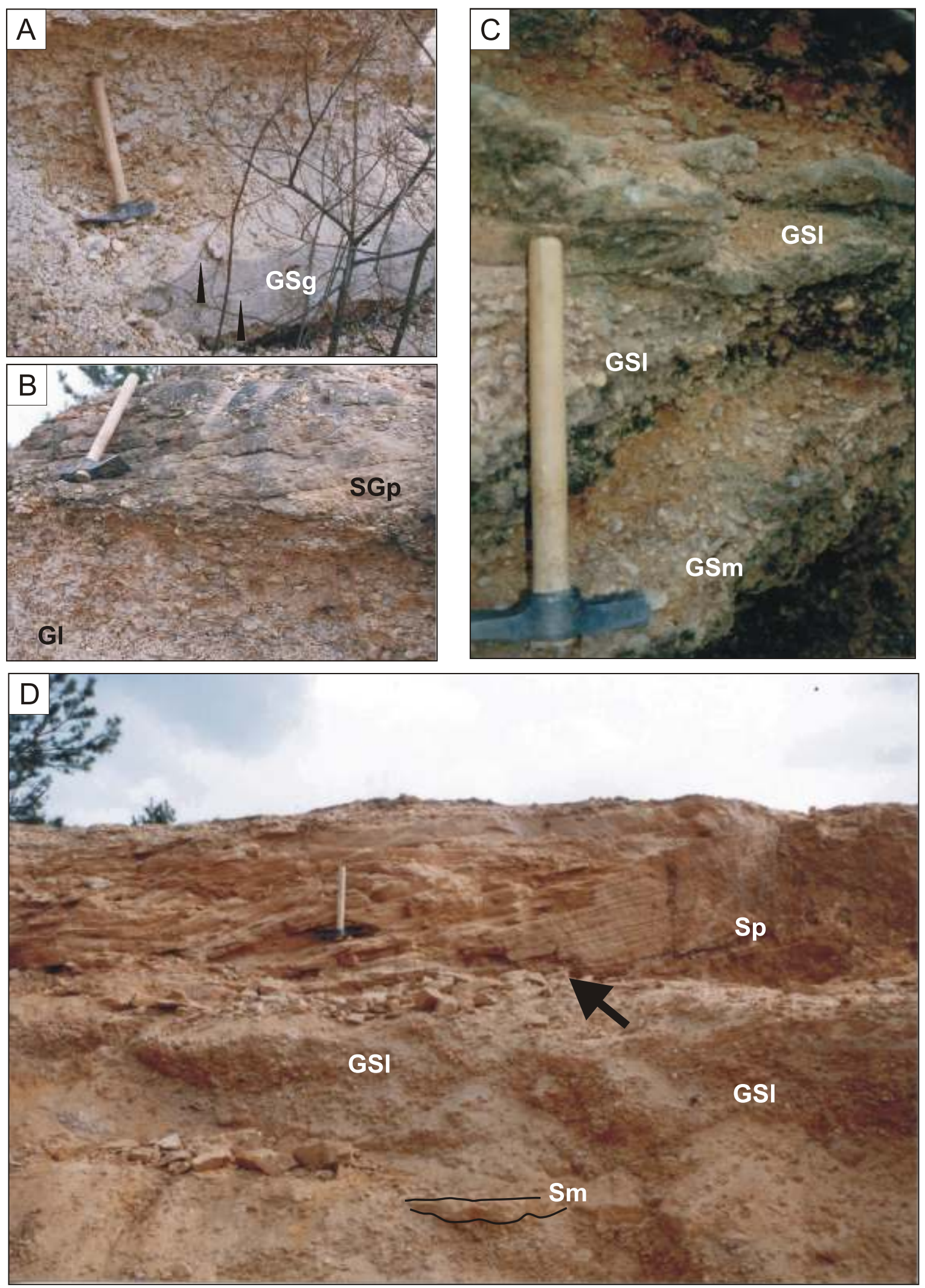

Fig. 6A - mixed gravelly-sandy deposits with normal grading (GSg), Snochowice wirownia-Skałki; B - contact of gravels with low-angle cross-bedding (GI) and gravelly sandstones with tabular cross-bedding (SGp), Snochowice wirownia-Skałki; C contact of massive sandy gravels (GSm) and low-angle cross-bedded sandy gravels (GSI), Snochowice wirownia-Skałki; D contact (black arrow) of sandy gravels with low-angle cross-bedding (GSl) and sandstones with tabular cross-bedding (Sp); among the gravelly deposits are visible some lenses of massive sandstone (Sm); Snochowice wirownia-Skałki 


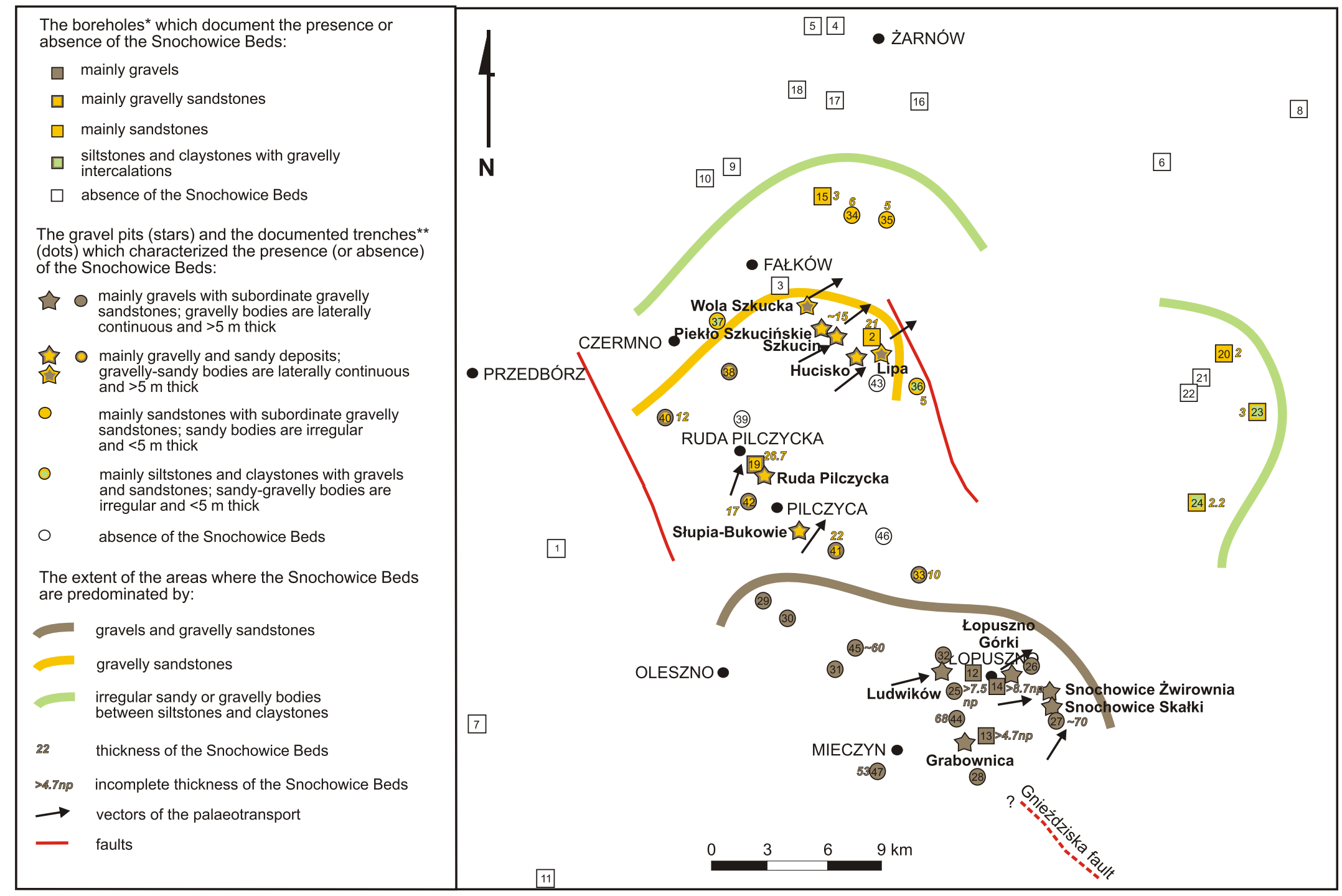

mainly gravelly sandstones

tercalations

gravel pits (stars) and the documented trenches* he presence (or absence) of the Snochowice Beds: mainly sandstones with subordinate gravelly

mainly siltstones and claystones with gravels

The extent of the areas where the Snochowice Beds are predominated by:

gravels and gravelly sandstones

gravelly sandstones

Fig. 7. The regional extent and the lithological variation of the Snochowice Beds in the western part of the MHCM (detailed data from archived boreholes records and from fieldwork; Kozłowska-Deuszkiewicz, 2005)

*boreholes: 1 - Bo a Wola IG 1, 2 - Lipa, 3 - Fałków 1, 4-Pilichowice, 5 - Myślibórz 1C10, 6 - Turowice 2, 7 - Pagów IG 1, 8 - Nieświń IG 1,9-Turowice TC 1, 10 - Turowice TC2, 11 Włoszczowa IG 1, 12 - Łopuszno, 13 - Łopuszno 1, 14 - Łopuszno 5, 15 - “101” arnów, 16 - “78” arnów, 17 - “67” arnów, 18 - “49” arnów, 19 - “41” Czermno, 20 - “6” Radoszyce, 21 - "10" Radoszyce, 22 - "13"Radoszyce, 23 - "14" Radoszyce, 24 - "19" Radoszyce; **25-51- the trenches where the Snochowice Beds have been analysed and documented; the thicknes was estimated on the base of the field work and combined with data from the geological maps (after Jurkiewiczowa, 1962a, $b$; Filonowicz and Lindner, 1982; Kwapisz, 1983; Janiec, 1993) 
fine-grained sandstones and silty deposits. The margin of this third area is designated by the light green line on Figure 7.

Generally near Fałków and towards the north-east the Snochowice Beds are discontinuous or absent. The Lower Jurassic succession is dominated by muddy-sandy deposits with plant remains and with coal layers (Jurkiewiczowa, 1967; Janiec, 1993). The fine-grained deposits with plant remains are included into the Zagaje Formation (sensu Pieńkowski, 2004).

To the SW of the Mieczyn-Oleszno-Przedbórz line, in the Pągów IG 1 borehole, Jurkiewicz (1976) did not find any coarse-grained deposits in the lowermost part of the Jurassic succession. According to Jurkiewicz (1976), only younger units of the Lower Jurassic are present: fine-grained deposit which overlie the Triassic basement. Thus, the Snochowice Beds seem to be absent there.

The Snochowice Beds are composed of alluvial cycles, approximately 2-3 metres thick. The lowermost part of the cycles usually consists of massive deposits. They are overlain by the gravelly beds with horizontal or cross-bedding, intercalated with massive, clast-supported gravels. The gravels are usually overlain by sandstones and gravelly sandstones with planar cross-bedding. Very rarely white, massive muds and clays of the $\mathrm{F}$ association occur in the topmost parts of the cyclic sequences.

\section{ANALYSIS OF PALAEOTRANSPORT DIRECTIONS}

The reconstruction of the Snochowice Beds transport directions is based on measurements of cross-bedding and the orientations of the longest axes of prolate pebbles. The resultant mean vector varies and ranges between 20 and $122^{\circ}$ (Figs. 3, 4 and 7). Thus the general palaeotransport direction was within a range between NNE and SE.

These results conflict with those reported by Dadlez (1962), which suggested, on the basis of analysis of pebble grain-size lateral variability in a few selected sections, a general palaeotransport direction towards the NW. In the Snochowice gravel pits the maximum diameter of pebbles was $15 \mathrm{~cm}$, and toward the NW, near Pilczyca, it drops to just $5 \mathrm{~cm}$. Meanwhile, around Lipa and Hucisko (located towards the NE of the Pilczyca region) pebbles larger than $10 \mathrm{~cm}$ have been found (Kozłowska-Deuszkiewicz, 2005). The relationship described by Dadlez (1962) is not obvious - there is no visible tendency of pebble diameter decrease in a NW direction.

A NE direction of palaeotransport was also postulated for the earliest Jurassic by Pieńkowski (2004; fig. 24A, B). Palaeotransport direction between the NNE and SE is perpendicular to the main fault zones and this may suggest synsedimentary fault activity during the Snochowice Beds sedimentation. Early Hettangian tectonic activity in the basin was also postulated by Brański (2006). Finally, the tectonic movements at the end of Triassic/at the beginning of Jurassic were described by Hakenberg and Świdrowska (1997) and Pieńkowski (2004), though in the eastern part of the MHCM. The tectonic activity created a geomorphological gradient, probably triggering a higher supply of coarse material from the source area and sedimentation of coarse-grained deposits during the early Hettangian.

\section{SEDIMENTARY PROCESSES}

The observations of the internal character, lateral extent, thickness and facies successions allow interpretion of the sedimentary processes which formed the Snochowice Beds.

The general characteristic of $\mathrm{M}$ association, mainly composed of GDm and GSm lithofacies, such as massive and ungraded structure, poor sorting, a high content of silty-clayey or sandy matrix, an irregular though tabular character of gravelly beds are consistent with formation as debris flow deposits. In widely accepted definitions (e.g., Schultz, 1984; Nemec and Steel, 1984; Postma, 1986; Blair and McPherson, 1998; Major, 2003) debris flow deposits are the products of gravity-driven flows of viscous (plastic), highly concentrated mixtures of sediment and water, often formed in subaerial conditions. Their sedimentary features resulted from gravity flow mechanisms: they accumulated because a decrease in gradient reduced internal shear (Nemec and Steel, 1984; Postma, 1986). In effect typical debris flow deposits are poorly sorted, structureless, clastto matrix-supported and ungraded (Schultz, 1984; Nemec and Steel, 1984; Postma, 1986). According to Nemec and Steel (1984) debris flow deposits are characterized by a few attributes: usually sheetlike or lenticular geometry of beds, limited erosional character of lower boundary and clast- to matrix-supported fabric. Nemec and Steel (1984) suggested that the texture of debris flow deposits varies from poly- to bimodal. A high correlation between clast size and bed thickness has been observed. Maizels (1989) restricted debris flow deposits to the products of viscous, high yield strength and high sediment concentration (>70\% detrital material in sediment-water mixture) types of flow with buoyancy and yield strength as dominant clast-support mechanisms. Thus, only massive, structureless, non-graded, poorly sorted and matrix-supported gravels could be interpreted as debris flow deposits. According to Maizels (1989) clast-supported deposits have different interpretations. They are products of hyperconcentrated flow, when the detrital material content is between 40 and $70 \%$ of sediment-water mixtures. Recognition of flow type in ancient environments is possible based on sedimentary structures, fabric and bed boundary characters. Coussot and Meunier (1996) proposed a simple classification for structureless, poorly sorted gravity flow deposits, based on the ratio between the cohesive, muddy matrix and the cohesionless, gravelly material. If their proportions are similar, they represent typically (plastic) debris flow deposits. Where coarse pebbles/boulders are tend to dominate and the content of silty-clayey matrix is smaller, the deposits should be treated as a "granular" debris flow deposits (the clast-rich debris flow deposits in Schultz's 1984 classification). For example in the Cretaceous alluvial fans successions described by Sohn et al. (1997) from the northwestern part of the Cretaceous Yongdong Basin in Central Korea, the massive, structureless conglomerates with a clast-supported fabric were interpreted as debris flow deposits. The high content of pebbles and cobbles and low content of muddy matrix suggested that the debris flows were cohesionless and dominated by frictional grain interactions. Eyles and Kocsis (1988) regarded the diamict facies with variable content of muddy matrix of Late Pleistocene deposits of Bow Valley in the Canadian Rocky 
Mountains as debris flow facies. In these two cases, the gravity mass flow processes were quite different but the sedimentary features, described as characteristic of debris flow deposits, are the same: a massive structure, a variable content of muddy matrix and poor sorting of gravelly material (Eyles and Kocsis, 1988; Sohn et al., 1997). Similarly, the M association deposits of the Snochowice Beds, especially the GDm lithofacies, are interpreted as a type of debris flow deposit. The high content of coarse, cohesionless material in the GSm lithofacies, suggests they are "granular" (clast-rich) debris flow deposits. This interpretation is supported by features such as the tabular or lenticular shape of the beds and the slightly erosional character of the lower boundaries (Table 2).

The stratified gravelly deposits of the Snochowice Beds (the $\mathrm{G}$ association) have a similar internal architecture and sedimentary structures to gravelly bedform and bar deposits. The gravel beds with cross-bedding and horizontal bedding were formed probably in the channel zones as longitudinal gravel bars during flooding episodes. The growth of the gravelly bars was the effect of aggradation and progradation in different parts of the channel zone as flow velocity decreased. These processes were not regular - they were strongly affected by the nature of the braided-river gravel transport. The migration of longitudinal and transverse gravel bars is a typical process in the braided river and stream environment (e.g., William and Rust, 1969; Rust, 1972, 1978; Miall, 1977, 1996). During episodes of high water and sediment discharge, sheets of gravels with horizontal bedding and low-angle cross-bedding are formed (Miall, 1996; Zieliński, 1997). Usually, downstream and upstream of the macroforms the mean pebble diameter decreases, and a fining upwards tendency is observed in the gravel packages (Rust, 1972; Zieliński, 1997).

Thick beds of conglomerate with different types of cross-bedding and horizontal bedding have been described from the upper Proterozoic deposits of central Arizona (Middleton and Trujillo, 1984) and also from the upper Paleozoic deposits of the Cape Basin in South Africa (Vos and Tankard, 1981) as well as from Pleistocene deposits in northeastern Poland (Zieliński, 1993). They have been interpreted as the products of gravelly bars and bedforms formed in channel zones during flood events.

The interpretation of the depositional environment of the $\mathrm{S}$ association is made by comparison with both recent and ancient analogues. The individual, thin $(<0.5 \mathrm{~m})$ and irregular lenses of tabular cross-bedded sandstone likely represent sedimentation on the topmost parts of longitudinal gravelly bars. This process is common in recent rivers, as flow energy decreases at the ends of flood stages. In effect, the rest of the coarse (sandy) material is deposited then (Miall, 1996). Sand sedimentation events at the ends of floods are brief and tend to form thin, individual sandy beds, from 0.3 to $0.5 \mathrm{~m}$ thick (Rust, 1972; Zieliński, 1997).

The appearance of thick packages of cross-bedded sandstones, which overlie the gravelly associations, should be used as indicators of changes in fluvial style deposition, which may be connected with a change in the river's hydrological regime (Miall, 1996; Zieliński, 1998). Such on explanation is applicable to the Snochowice Beds, especially because the thickness of individual cross-sets is up to $0.5 \mathrm{~m}$. Similar changes in the hydrological regime have been observed in recent fluvial environments (William and Rust, 1969; Rust, 1972; Miall, 1996).

Changes in depositional style following changes in hydrological regime were noted by Brierley (1991) in the Squamish River channel zone. Packages of cross-bedded sands, a few metres thick, formed during the migration of transverse sandy bars. These particular bedsets of sandy-gravelly material in the Squamish River are more than $0.5 \mathrm{~m}$ thick and the packages of sandy deposits are underlain by the gravelly bar deposits. Bridge and Gabel (1992) described sandy-gravelly deposits with a different type of cross-bedding from the Calamus River in the Nebraska Sand Hills. These formed as sandy bars and bedforms as an effect of changes in the velocity of flow in the channel zone. Zieliński (1997) observed tabular cross-bedded sandy-gravelly deposits in the Pleistocene in northeastern Poland, interpreted as sandy bar deposits of a channel zone. The sedimentary features and geometry of the Snochowice Beds sandy deposits are interpreted similarly.

Deposition of the F association was probably connected with flow decrease in the channel zone between individual flood stages (Miall, 1996). Such processes take place in a semi-arid or arid climate, when channel flow only takes place after intense rainfall (Williams and Rust, 1969; Rust, 1972). Mud and clay deposition may take place on the inactivate gravel bars, gravel where sedimentation has shifted to another part of the channel belt, as a result of avulsion processes. Deposits of this association appear only rarely in braided river and stream successions because they are usually eroded during the next flood. Hence, small thickness and low frequency of this association in the Snochowice Beds sections.

\section{SEDIMENTARY ENVIRONMENT OF THE SNOCHOWICE BEDS}

The sedimentological analyses have allowed characterization of the main sedimentary features and internal geometry of the Snochowice Beds. They are following:

- a relatively high frequency of the $\mathrm{M}$ association in sections in the Łopuszno area (Fig. 3);

- a rapid decrease in clast size towards the transport direction (north and north-east; Fig. 7);

- a rapid decrease in the frequency of the gravelly lithofacies and an increasing frequency of the sandy lithofacies generally towards the transport direction (north and north-east; Figs. 3, 4 and 7);

- a rapid decrease in thickness generally towards the transport direction (north and north-east);

- a limited radial extent, restricted to about 20-25 kilometres (Fig. 7).

In many ancient and recent successions such sedimentary features and internal geometry have been treated as indicators of alluvial fan sedimentation (Stanistreet and McCarthy, 1983; Collinson, 1996; Blair and McPherson, 1994; Harvey et al., 2005). During the last twenty years, sedimentologists have discussed the meaning of the term "alluvial fans". In consequence this term has been restricted by some authors (e.g., Blair and McPherson, 1994; Smith, 2000) to packages of coarse-grained 
deposits, which formed landforms (macroforms) of semi-conical shape in plan view and restricted to few kilometres, associated with mountainous relief or with tectonically activated escarpments. The main processes on alluvial fans proper (also named as piedmont alluvial fans) are sheet flows, which produced mainly tabular, planar-bedded couplets of coarse-grained sediments and gravity flow deposits, typically as structureless, poorly sorted, massive deposits (mainly debris flow deposits). Successions of streamflow deposits are very rare on typical alluvial fans. Similar in semi-conical shape are the widespread alluvial landforms, developed near highlands and near active fault zones, which are dominated by deposition of decimetre-scale or metre-scale, cross-bedded bar forms, connected with shallow, channelized flows on the alluvial slopes. Such landforms are termed alluvial, streamflow-dominated fans (Smith, 2000). The useful classification proposed by Stanistreet and McCarthy (1993) for alluvial fans and landforms is based on the main sedimentological processes on the slopes, on the extent of the landforms and on the dip of slopes. They have distinguished three main type of alluvial macroform: (1) debris flow-dominated fans, (2) braided river-dominated fans and (3) meandering river-dominated fans. In the first type, the main depositional phenomena are channelized debris flows, sheet flows and shallow braided streams processes, forming mainly beds of poorly sorted, massive gravels with high contents of muddy matrix - typical debris flow deposits. These forms are steep and a few kilometres in extent, similarly to the alluvial fans described by Blair and McPherson (1994). The braided river-dominated fans are characterized by deposition in distributive channels of short-range braided streams. The successions are dominated by clast-supported gravels and gravelly sandstones, with cross- and horizontal crude bedding indicating deposition of the gravelly bars and bed forms in braided streams. The Snochowice Beds, which are dominated by the gravelly bar deposits and smaller amounts of debris flow deposits, represent rather the second type of alluvial landform of Stanistreet and McCarthy's (1993) classification or the streamflow-dominated fans of Smith (2000). Sedimentation on Early Jurassic alluvial landforms dominated by shallow, braided streams intermittently interrupted by debris flow processes is also indicated by vertical and lateral lithofacies variations, decrease in total thickness and decrease in clast size along the palaeotransport directions. Near Łopuszno, gravel bar deposits and sediment-gravity flow deposits are dominant. In this zone the thickness of the Snochowice Beds is up to $70 \mathrm{~m}$. The high content of the M association indicates the importance of debris flow processes during deposition (Figs. 7 and 8). The Łopuszno area probably represents proximal parts of the alluvial landforms. Near Pilczyca, Ruda Pilczycka and Szkucin, the Snochowice Beds are composed of cross-bedded gravels and sandstones, the product of gravelly and sandy bars in the channel zones of short-range braided streams, probably in the distal parts of the alluvial landforms (Figs. 7 and 8). North and north-east of Żarnów the Snochowice Beds disappear and east of Żarnów they are strongly reduced and restricted only to sandstones (as well as in Pilichowice borehole; see Pieńkowski, 2004). Here, the coarse-grained deposits occur only as fine-grained gravels or gravelly sandstones, usually less than $1 \mathrm{~m}$ thick, and as irregular lenses generally fine-grained in the Zagaje Formation (Jurkiewiczowa, 1967; Pieńkowski, 2004). This is the area where the Snochowice Beds pass laterally into the Zagaje Formation (Figs. 8 and 9).

In most cases the alluvial fan breccias and conglomerates are composed of angular/subangular clasts of local rocks (e.g., Larsen and Steel, 1978; Blair, 1987; Hubert and Filipov, 1989; Blair and McPherson, 1994; Dade and Verdeyen, 2007). Commonly, a low roundness of clasts and low petrographic maturity are used as indicators of short and rapid gravity transport associated with alluvial fans. Petrographic studies of the Snochowice Beds show, though, high petrographic maturity and significant contents of well-rounded fragments of quartz and siliceous rocks, indicating long transport from distant source areas and/or multiple redeposition of pebbles from

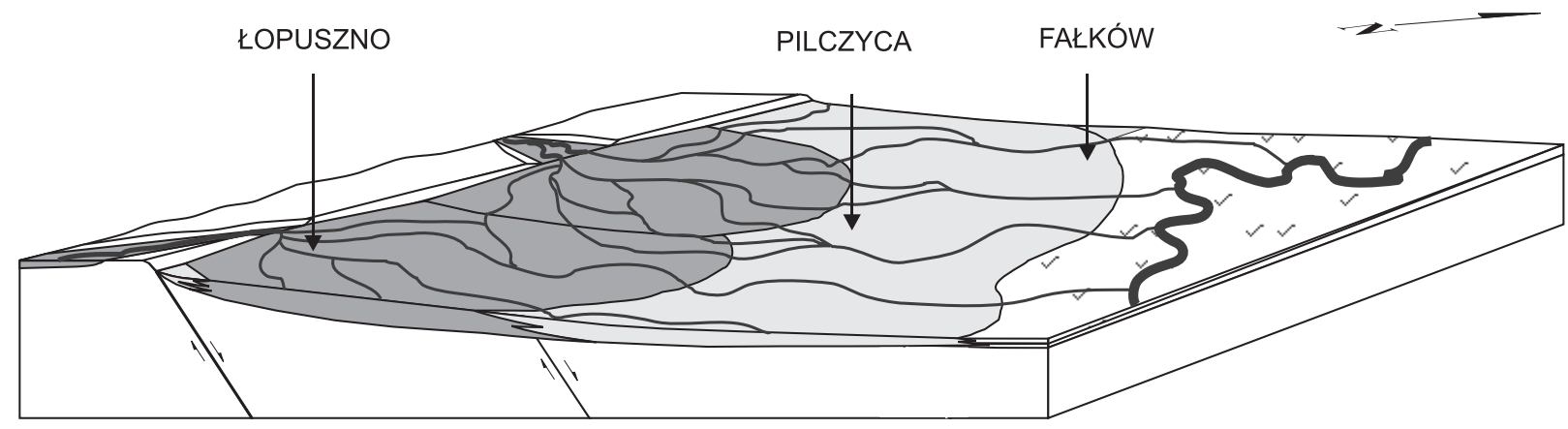

Triassic basement (claystones, siltstones)

synsedimentary faults gravelly deposits of the proximal part of the alluvial landforms predominantly

$M$ and $G$ associations sandy and gravelly deposits of the distal part of the alluvial landforms - predominantly

$S$ and $G$ associations silty-sandy deposits of the fluvial transfer area (meandering river sedimentary environment)

Fig. 8. Reconstruction of the Snochowice Beds sedimentary environment 


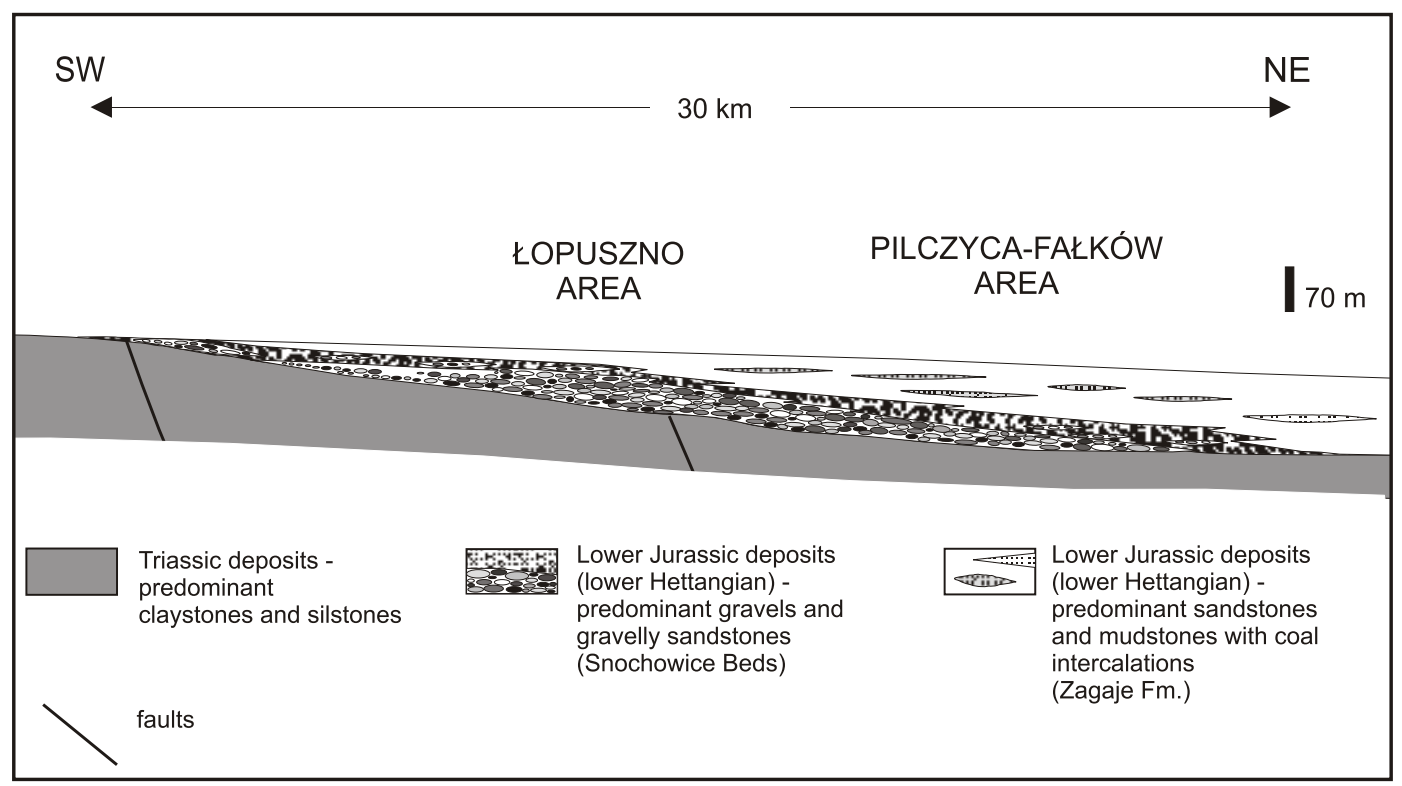

Fig. 9. Geological scheme of the relation between the Snochowice Beds and its age-equivalent (the Zagaje Formation)

older, gravelly rocks (Maliszewska, 1997; Kozłowska, 2011). The upland drainage basin, located to the south-west of the Mieczyn-Oleszno-Przedbórz line, is built mainly of the Norian/Rhaetian siltstones and claystones. Therefore, the erosion of Upper Triassic basement is an effect of Late Triassic/Early Jurassic structural reorganization in the MHCM, reading to supply of mainly clayey/silty material. Renewed subsidence of the Mid-Polish Trough Basin during the Mesozoic may have reactivated erosion in the source areas. So, from the Early Triassic into the Early Jurassic coarse (pebbly) material was supplied by streams and rivers to the MPT probably from older, gravelly source rocks from areas located far to the south and south-east (Teofilak-Maliszewska, 1968; Kozłowska, 2011). Late Triassic/Early Jurassic tectonic activity perhaps reactivated erosion in the drainage areas and older, probably Triassic, gravelly deposits composed of well-rounded pebbles of different siliceous rocks, were reworked. The composition of the Snochowice Beds may give misleading information concerning the distance between the drainage basin and deposition area, and should be treated with caution.

It is commonly supposed that tectonic activity plays a key role in controlling deposition on different alluvial fans systems (Collinson, 1996; Dade and Verdeyen, 2007). Subsidence, commonly expressed as the movements on fault escarpments, creates accommodation space, allowing deposition of thick gravelly deposits on different types of alluvial fan (North et al., 1989; Bentham et al., 1991; Viseras et al., 2003). Pulses of synsedimentary tectonic activity may reactivate the relief between the source and the fan areas, causing renewed erosion in the source area and higher sediment supply to the fan. In consequence these processes are responsible for the aggradation and progradation of alluvial fan depositional systems (North et al., 1989; Viseras et al., 2003). Alluvial fan sedimentation in tectonically controlled basins has been described by many authors (e.g., North et al., 1989; Bentham et al., 1991; Collinson, 1996;
Viseras et al., 2003). The Snochowice Beds comprises gravelly deposits, formed during increased subsidence in the MHCM. The pulses of tectonic activity produced reactivated relief during sedimentation, enabling deposition of $70 \mathrm{~m}$ of thick gravelly-sandy deposits of alluvial origin. The Snochowice Beds are not alone among Jurassic sequences of the MHCM deposited in tectonically-controlled basins. An increased rate of tectonic subsidence at the end of Triassic and at the beginning of the Early Jurassic has been commonly invoked (Dadlez et al., 1995; Hakenberg and Świdrowska, 1997; Poprawa, 1997; Pieńkowski, 2004). Similar deposits have been documented from the lowermost parts of the Hettangian profiles in the Miłków-Szewna and Podole boreholes (see the lowermost part of the Zagaje Fm. sensu Pieńkowski, 2004), in which gravelly deposits appeared as a result of Early Jurassic synsedimentary activity along the Ostrowiec Świętokrzyski Fault.

\section{SUMMARY}

The sedimentological analyses described herein included: (1) the detailed lithofacies identifications, (2) estimation of facies associations and their relations, (3) estimation of the thickness variations in the Snochowice Beds. Three zones of deposition were distinguished: the Łopuszno area, the Pilczyca-Fałków area and the area to north and north-east of arnów. In the Łopuszno area, the Snochowice Beds are fully developed and the $\mathrm{M}$ and $\mathrm{G}$ associations are dominant; in the Pilczyca-Fałków area the S and $\mathrm{G}$ associations are dominant; and north and north-east of arnów the Snochowice Beds are discontinuous with few or no thick gravelly packages. The relatively high frequency of gravelly bar and debris flow deposits, the rapid decrease of clast size, the thickness and frequency of the gravelly lithofacies simultaneously with increased fre- 
quency of the sandy lithofacies generally towards the transport direction suggest the alluvial character of sedimentation, similar to that described by Smith (2000). These Early Jurassic landforms are classified as a short-range alluvial landforms, dominated by fluvial processes, interrupted periodically by debris flows (streamflow dominated fans). Sedimentation was controlled by tectonic processes, specifically with activity of the Mieczyn-Oleszno-Przedbórz Fault Zone. Faulting areated accommodation space allowing deposition of thick, gravelly deposits and was also responsible for erosion of the drainage area. The depositional area received well-rounded, pebbly material, redeposited from older, probably Triassic gravels and conglomerates. The rapid increase in subsidence rate was restricted to the Rhaetian and Hettangian time interval, as took place also in other parts of the MHCM (Pieńkowski, 2004; Brański, 2006).
Acknowledgements. I thank Prof. P. Roniewicz for many helpful and perceptive discussions during my $\mathrm{PhD}$ studies, and while preparing this paper. I gratefully acknowledge Prof. T. Zieliński, my $\mathrm{PhD}$ reviewer and also my paper reviewer for his comments and suggestions regarding interpretation of the sedimentary environment of the Snochowice Beds. I would like to express also my warmest gratitude to Dr hab. A. Wysocka for her many and very helpful suggestions.

I thank Dr hab. G. Pieńkowski for helpful comments about the regional Jurassic geology of the Mesozoic margin of the Holy Cross Mountains. My special thanks go to Dr. D. Ventra for very useful sedimentological observations, suggestions regarding the organization of this paper and for providing relevant references to this paper.

\section{REFERENCES}

BARSKI M. (1999) - Dinocyst stratigraphy of the Jurassic black clays from Holy Cross Mts area (Central Poland) (in Polish with English summary). Prz. Geol., 47 (8): 718-722.

BENTHAM P., COLLIER R. E., GAWTHORPE R. L., LEEDER R. and STARK C. (1991) - Tectono-sedimentary development of an extensional basin: the Neogene Megara Basin, Greece. J. Geol., Soc., 148: 923-934.

BLAIR T. C. (1987) - Sedimentary processes, vertical stratification sequences and geomorphology of the Roaring River alluvial fan, Rocky Mountain National Park, Colorado. J. Sediment. Petrol., 57: 845-862.

BLAIR T. C. (1999) - Sedimentology of the debris-flow-dominated Warm Spring Canyon alluvial fan, Death Valley, California. Sedimentology, 46 (5): 941-965.

BLAIR T. C. and McPHERSON J. G. (1994) - Alluvial fans and their natural distinction from rivers based on morphology, hydraulic processes, sedimentary processes, and facies assemblages. J. Sediment. Res., A64: 450-489.

BLAIR T. C. and McPHERSON J. G. (1998) - Recent debris-flow processes and resultant form and facies of the Dolomite alluvial fan, Owens Valley, California. J. Sediment. Res., 68 (5): 800-818.

BRAŃSKI P. (2006) - Lower Hettangian in the Holy Cross Mountains region - an example of tectonically-controlled sedimentation in the epicontinental basin of Poland. Vol. Jurassica, 4: 80-81.

BRIDGE J. S. and GABEL S. L. (1992) - Flow and sediment dynamics in a low sinuosity, braided river: Calamus River, Nebraska Sandhills. Sedimentology, 39: 125-142.

BRIERLEY G. J. (1991) - Bar sedimentology of the Squamish River, British Columbia: definition and application of morphostratigraphic units. J. Sediment. Petrol., 61: 211-225.

BUŁA Z. (2000) - The Lower Palaeozoic of the Upper Silesia and West Małopolska (in Polish with English summary). Prace Państw. Inst. Geol., 171: 1-89.

BUŁA Z., JACHOWICZ M. and ABA J. (1997) - Principal characteristics of the Upper Silesian Block and Małopolska Block border zone (southern Poland). Geol. Mag., 134 (5): 669-677.

COLLINSON J. D. (1996) - Alluvial sediments. In: Sedimentary Environments: Processes, Facies and Stratigraphy (ed. H. G. Reading): 37-81. Blackwell Science.

COUSSOT P. and MEUNIER M. (1996) - Recognition, classification and mechanical description of debris flows. Earth Sc. Rev., 40: 209-227.

CURRAY J. R. (1956) - The analysis of two-dimensional orientation data. J. Geol., 64: 117-131.
DADE W. B. and VERDEYEN M. E. (2007) - Tectonic and climatic controls of alluvial-fan size and source-catchment relief. J. Geol. Soc., 164: 353-358.

DADLEZ R. (1962) - Equivalents of the Połomia beds of the Częstochowa Lias in the Western Margin area of the Święty Krzy Mountains (in Polish with English summary). Geol. Quart., 6 (3): 447-458.

DADLEZ R. (1982) - Permian-Mesozoic tectonics versus basement fractures along the Teisseyre-Tornquist Zone in the territory of Poland (in Polish with English summary). Geol. Quart., 26 (2): 273-284.

DADLEZ R. (2006) - The Polish Basin - relationships between the crystalline, consolidated and sedimentary crust. Geol. Quart., 50 (1): 43-57.

DADLEZ R., NARKIEWICZ M., STEPHENSON R. A., VISSER M. T. M. and van WEES J-D. (1995) - Tectonic evolution of the Mid-Polish Trough: modelling implications and significance for central European geology. Tectonophysics, 252: 179-195.

EYLES N. and KOCSIS S. (1988) - Sedimentology and clast fabric of subaerial debris flow facies in a glacially-influenced alluvial fan. Sediment. Geol., 59: 15-28.

FILONOWICZ P. and LINDNER L. (1982) - Szczegółowa Mapa Geologiczna Polski w skali 1:50 000, ark. Piekoszów. Wyd. Geol., Warszawa.

GUTERCH A., GRAD M., MATERZOK R. and PERCHUC E. (1986) Deep structure of the Earth's crust in the contact zone of the Paleozoic and Precambrian platform in Poland (Tornquist-Teisseyre Zone). Tectonophysics, 128: 251-279.

HAKENBERG M. and ŚWIDROWSKA J. (1997) - Propagation of the southeastern segment of the Polish Trough connected with bounding fault zones (from Permian to Late Jurassic). Comptes rendus de l'Acad. des Sc. Paris, 324: 793-803.

HARVEY A. M. (1984) - Debris flows and fluvial deposits in Spanish Quaternary alluvial fans: implications for fan morphology. Can.. Soc. Petrol. Geol., 10: 123-132.

HARVEY A. M., MATHER A. E. and STOKES M. (2005) - Alluvial fans: geomorphology, sedimentology, dynamics - introduction. A review of alluvial-fan research. Geol. Soc. Spec. Publ., 251: 1-7.

HUBERT J. F. and FILIPOV A. J. (1989) - Debris flow deposits in alluvial fans on the west flank of the White Mountains, Owens Valley, California. Sediment. Geol., 61: 177-205.

JANIEC J. (1993) - Szczegółowa Mapa Geologiczna Polski w skali 1:50 000, ark. arnów. Wyd. Geol., Warszawa.

JURKIEWICZ H. (1976) - Dolna jura. In: Pągów IG-1. Profile głębokich otworów wiertniczych. Inst. Geol., 33: 38-39. 
JURKIEWICZOWA I. (1962a) - Szczegółowa Mapa Geologiczna Polski w skali 1:50 000, ark. Czermno. Wyd. Geol., Warszawa.

JURKIEWICZOWA I. (1962b) - Szczegółowa Mapa Geologiczna Polski w skali 1:50 000, ark. Radoszyce. Wyd. Geol., Warszawa.

JURKIEWICZOWA I. (1967) - The Liass of the western part of the Mesozoic zone surrounding the Święty Krzy Mountains and its correlation with the Lias of the Cracow-Wielun Range (in Polish with English summary). Biul. Inst. Geol., 200 (2): 5-132.

KARASZEWSKI W. (1960) - New division of the Święty Krzy Lias (in Polish with English summary). Kwart. Geol., 4 (4): 899-921.

KARASZEWSKI W. (1962) - The stratigraphy of the Lias in the Northern Mesozoic Zone surrounding the Święty Krzy Mountains (Central Poland) (in Polish with English summary). Prace Inst. Geol., 30: 333-416.

KARASZEWSKI W. and KOPIK J. (1970) - Lower Jurassic (in Polish, with English summary). Prace Inst. Geol., 56: 65-93.

KOSTECKA A. (1962) - Characteristic of Zechstein conglomerates in Gałęzice-Bolechowice Syncline (Święty Krzy Mountains) (in Polish with English summary). Kwart. Geol., 6 (3): 416-435.

KOZŁOWSKA-DEUSZKIEWICZ M. (2005) - Charakterystyka sedymentologiczna liasowych warstw snochowickich (zachodnie obrze enie mezozoiczne Gór Świętokrzyskich) i warstw połomskich (obszar krakowsko-wieluński). Unpubl. PhD thesis. Arch. Uniw. Warszawskiego.

KOZŁOWSKA M. (2011) - The petrography of the Snochowice Beds (Lower Jurassic, western Mesozoic margin of the Holy Cross Mountains) (in Polish with English summary). Prz. Geol., 59 (7): 523-534.

KUTEK J. and GŁAZEK J. (1972) - The Holy Cross area, Central Poland, in the Alpine cycle. Acta Geol. Pol., 22 (4): 603-653.

KWAPISZ B. (1983) - Szczegółowa Mapa Geologiczna Polski w skali 1:50 000, ark. Oleszno. Wyd. Geol., Warszawa.

LARSEN V. and STEEL R. J. (1978) - The sedimentary history of a debris-flow dominated Devonian alluvial fan - study of textural inversion. Sedimentology, 25: 37-59.

MAIZELS J. (1989) - Sedimentology, paleoflow dynamics and flood history of Jokulhlaup deposits: paleohydrology of Holocene sediment sequences in southern Iceland sandur deposits. J. Sediment. Petrol., 59 (2): 204-223.

MAJOR A. M. (2003) - Debris flow. In: Encyclopedia of Sediments and Sedimentary Rocks (ed. G. V. Middleton). Kluwer Academic Encyclopedia of Earth Sciences Series: 186-188. Kluwer Acad. Publ., Dordrecht.

MALISZEWSKA A. (1997) - Charakterystyka petrograficzna. In: Epicontinental Permian and Mesozoic in Poland (in Polish with English summary). Prace Państw. Inst. Geol., 153: 206-208.

MARCINKIEWICZ T. (1971) - The stratigraphy of the Rhaetian and Lias in Poland based on megaspore investigations (in Polish with English summary). Prace Inst. Geol., 65: 1-58.

MAREK S. (1988) - Paleothickness, facies and paleotectonic maps of the epicontinental Permian and Mesozoic in Poland (in Polish with English summary). Kwart. Geol., 32 (1): 1-14.

MIALL A. D. (1977) - A review of the braided river depositional environment. Earth Sc. Rev., 13: 1-62.

MIALLA. D. (1996) - The Geology of fluvial deposits sedimentary facies, basin analysis, and petroleum geology. Springer-Verlag, Berlin.

MIDDLETON L. T. and TRUJILLO A. P. (1984) - Sedimentology and depositional setting of the U. Proterozoic Scanlan Conglomerate, central Arizona. Can. Soc. Petrol. Geol., 10: 189-201.

NEMEC W. and STEEL R. J. (1984) - Alluvial and coastal conglomerates: their significant features and some comments on gravelly mass-flow deposits. Can. Soc. Petrol. Geol., 10: 1-31.

NORTH C. P., TODD S. P. and TURNER J. P. (1989) - Alluvial fans and their tectonic controls. J. Geol. Soc., 146: 507-508.

PAWŁOWSKA K. (1962) - The Rhaetian and the Lias of the southern periphery of the Swiety Cross Mountains (in Polish with English summary). Kwart. Geol., 6 (3): 436-446.

PIEŃKOWSKI G. (1980) - Sedymentologia dolnego liasu północnego obrze enia Gór Świętokrzyskich. Unpubl. PhD thesis. Arch. Uniw. Warszawskiego.
PIEŃKOWSKI G. (1983) - Early Lias sedimentary environments at the northern margin of the Holy Cross Mountains (in Polish with English summary). Prz. Geol., 31 (4): 223-231.

PIEŃKOWSKI G. (2004) - The epicontinental Lower Jurassic of Poland. Polish Geol. Inst. Spec. Pap., 12: 1-154.

PIEŃKOWSKI G. (2006) - Field trip B4. In: Jurassic of Poland and adjacent Slovakian Carpathians (eds. A. Wierzbowski, A. Aubrecht, J. Golonka, J. Gutowski, M. Krobicki, B. A. Matyja, G. Pieńkowski and A. Uchman). Field trip guidebook of 7 th International Congress on the Jurassic System Poland, Kraków, September 6-18, 2006. Państw. Inst. Geol.

POPRAWA P. (1997) - Late Permian to Tertiary dynamics of the Polish Trough. Trans European Suture Zone, Europrobe TESZ - Meeting. Terra Nostra, 11: 104-109.

POSTMA G. (1986) - Classification for sediment gravity-flow deposits based on flow conditions during sedimentation. Geology, 14 291-294.

RUST B. R. (1972) - Structure and processes in a braided river. Sedimentology, 18: 221-245.

RUST B. R. (1978) - A classification of alluvial channel systems. Can. Soc. Petrol. Geol. Mem., 5: 187-198.

SCHECK-WENDEROTH M., KRZYWIEC P., ZÜHLKE R., MAYSTRENKO Y. and FROITZHEIM N. (2008) - Permian to Cretaceous tectonics. In: The Geology of Central Europe. Volume 2: Mesozoic and Cenozoic (ed. T. McCann): 999-1030. Geol. Soc., London.

SCHULTZ A. W. (1984) - Subaerial debris-flow deposition in the Upper Paleozoic Cutler Fm, western Colorado. J. Sediment. Petrol., 54: $759-772$.

SMITH G. A. (2000) - Recognition and significance of streamflow-dominated piedmont facies in extensional basin. Basin Res., 12: 399-411.

SOHN Y. K., RHEE C. W. and KIM B. C. (1997) - Debris flow and hyperconcentrated flood-flow deposits in an alluvial fan, northwestern part of the Cretaceous Yongdong basin, central Korea. J. Geol., 107: 111-132.

STANISTREET I. G. and McCARTHY T. S. (1993) - The Okavango Fan and the classification of subaerial fan systems. Sediment. Geol., 85: $115-133$.

TEOFILAK-MALISZEWSKA A. (1968) - Petrography of Liassic deposits in the northern margin of the Świętokrzyskie Mountains (in Polish with English summary). Biul. Inst. Geol., 216: 107-190.

UNRUG R. (1957) - Recent transport and sedimentation of gravels in the Dunajec valley (western Carpathians) (in Polish with English summary). Acta Geol. Pol., 7 (2): 217-257.

VISERAS C., CALVACHE M. L., SORIA J. M. and FERNANDEZ J. (2003) - Differential features of alluvial fans controlled by tectonic or eustatic accomodation space. Examples from the Betic Cordillera, Spain. Geomorphology, 50: 181-202.

VOS R. G. and TANKARD A. J. (1981) - Braided fluvial sedimentation in the Lower Paleozoic Cape Basin, S. Africa. Sediment. Geol., 29: 171-193.

WILLIAM P. F. and RUST B. R. (1969) - The sedimentology of a braided river. J. Sediment. Petrol., 39 (2): 649-679.

WRÓBLEWSKI T. (2000) - Mapa chronionych obszarów i obiektów przyrody nieo ywionej 1:200 000. Wyd. Kartograficzne Polskiej Agencji Ekologicznej S.A. Warszawa.

ZIEGLER P. A. (1992) - North Sea Rift System. Tectonophysics, 208: 55-75.

ZIELIŃSKI T. (1993) - Sandry Polski północno-wschodniej - osady i warunki sedymentacji. Prace Nauk. Uniw. Śl., 1398: 1-97.

ZIELIŃSKI T. (1997) - The cyclicity in the braided rivers deposits (in Polish with English summary). Prace Nauk. Uniw. Śl., 1644. Geologia, 14: $68-119$

ZIELIŃSKI T. (1998) — Litofacjalna identyfikacja osadów rzecznych. In: Struktury sedymentacyjne i postsedymentacyjne w utworach czwartorzędowych i ich wartość interpretacyjna (ed. E. Mycielska-Dowgiałło): 195-260. Wyd. Uniw. Warszawskiego. 